\title{
Effect of Salinity to change on ionic Composition in D. sissoo and A. nilotica
}

\author{
Dharamvir*, Ajeev Kumar, Mahesh Kumar and Parveen Kumar \\ Department of Botany and Plant Physiology, CCS Haryana Agricultural University, Hisar- \\ 125 004, Haryana, India \\ *Corresponding author
}

\begin{tabular}{|l|}
\hline Ke y w o r d s \\
Acacia nilotica, \\
$\begin{array}{l}\text { Chloride, Dalbergia } \\
\text { sissoo, Salinity, } \\
\text { Sodium and } \\
\text { Sulphate }\end{array}$ \\
\hline Article Info \\
\hline $\begin{array}{l}\text { Accepted: } \\
\text { 26 November } 2018 \\
\text { Available Online: } \\
\text { 10 December } 2018\end{array}$ \\
\hline \hline
\end{tabular}

\section{A B S T R A C T}

For the past hundreds of year's trees like Dalbergia sissoo (Shisham), Acacia nilotica (Kikar), Prosopis cinneraria (Khejri) etc. have inhabited vast areas in the plains of Afghanistan, Pakistan, India, Nepal and Myanmar. These have also been widely used for afforestation in many parts of the country except in the very hot, cold and wet tracts. These have good atmospheric $\mathrm{N}_{2}{ }^{-}$fixing ability, therefore, are extensively planted in social and agro-forestry programmes. In order to evaluate the effect of soil salinity, present investigation was conducted on two tree species i.e. Dalbergia sissoo Roxb. ex DC (Shisham) and Acacia nilotica (L.) willd. ex Delile (Kikar) growing under field conditions in Hisar district during the year 2011-2012. In Dalbergia sissoo the mean sodium was $2.13 \mathrm{mg} / \mathrm{g}$ which was significantly lower than $9.06 \mathrm{mg} / \mathrm{g}$ obtained under saline conditions. Mean value of Sodium in Acacia nilotica also showed significant increase in non-saline over saline site trees. In Dalbergia sissoo under non saline conditions the mean potassium was $30.98 \mathrm{mg} / \mathrm{g}$ which was significantly higher than $23.73 \mathrm{mg} / \mathrm{g}$ obtained under saline environment and the mean value of potassium in Acacia nilotica also showed significant decrease in saline over non-saline site trees. Further it is obvious in Dalbergia sissoo, under non saline conditions the mean $\mathrm{Na}: \mathrm{K}$ was 0.068 which was significantly lower than 0.38 obtained under the saline environment. In Acacia nilotica the mean $\mathrm{Na}: \mathrm{K}$ value was 0.072 under non-saline conditions which was significantly and many fold lower than 0.44 obtained at saline sites. Under non saline conditions the mean chloride was $1.21 \mathrm{mg} / \mathrm{g}$ which was significantly lower than $5.03 \mathrm{mg} / \mathrm{g}$ obtained under saline environment in Dalbergia sissoo. The mean value of chloride in Acacia nilotica also showed significant increase in non-saline over saline site trees. Further in Dalbergia sissoo it is seen that under non saline conditions the mean Sulphate was $2.34 \mathrm{mg} / \mathrm{g}$ which was significantly lower than $7.76 \mathrm{mg} / \mathrm{g}$ obtained under saline environment sites. The mean sulphate was $2.33 \mathrm{mg} / \mathrm{g}$ under non-saline conditions which was significantly lower than $8.18 \mathrm{mg} / \mathrm{g}$ obtained at the saline sites in Acacia nilotica. Hence, the mechanism of salt tolerance is relatively better in Acacia nilotica than in Dalbergia sissoo as found from physiological and biochemical studies. 


\section{Introduction}

Salinity toxicity normally results when certain ions are taken up with the soil- water and accumulate in the leaves during water transpiration to an extent that result in damage to the plant. The degree of damage depends upon time, concentration, crop sensitivity and crop water used, and if damage is severe enough, crop yield is reduced. The usual toxic ions in irrigation water are chloride, sodium and boron. Damage can be caused by each, individually or in combination (Tanji 1990).

Due to their large size and perennial nature trees have attracted attention of few workers as compared to herbaceous crop plants with respect to salinity toxicity related investigations under field conditions. Importance the adverse effects of secondary salinity and importance of tree planting for the reclamation of salt-affected lands was recognized by Schofield (1992). Sun and Dickinson (1995) carried out studies in tropical North Australia, to compare tree response to soil salinity of Casuarina cunninghamiana and Eucalyptus camaldulensis grown on a saline site. Both species had a similarly high survival rate. Compared with $C$. cunninghamiana, $E$. camaldulensis trees were taller with greater DBH at both low and moderate salinity, and transpired more water in both summer and winter. C. cunninghamiana possessed a shallow root system with the bulk of the lateral roots in the upper $12 \mathrm{~cm}$ of soil, while E. camaldulensis had a deep root system with the majority of the lateral roots located in the upper $28 \mathrm{~cm}$. Hussain and Alshammary (2008) observed that the survival period of Acacia nilotica and Prosopis juliflora was significantly more than Eucalyptus camaldulensis and Parkinsonia aculeate under different water salinity levels and soil types. The total biomass decreased significantly with an increase in soil salinity. Soil salinity and sodicity increased significantly with increasing irrigation water salinity and sodicity. Tree survival and proper establishment was possible provided management practices such as a leaching requirement (at least 15\%), proper selection of trees, right irrigation water salinity, and proper planting methods was followed.

In India Tewari et al.(2006) observed growth responses of Dalbergia sissoo and Acacia nilotica seedlings on different levels of soil sodicity and salinity. The growth and dry weight of one-year old seedlings decreased as the level of sodicity and salinity increased in both species. However, the suppression in growth caused by sodicity and salinity was relatively greater in $D$. sissoo than in $A$. nilotica. A. nilotica showed wider response breadth compared with $D$. sissoo on both the gradients. Further, the response breadths were comparatively higher under sodicity levels than under salinity levels. Singh et al., (2007) noted that Dalbergia sissoo in its natural and man-influenced ecosystem was being adversely affected by various abiotic stresses. Studies undertaken on the physio-chemical characteristics of soil under dead and healthy trees of Dalbergiasissoo and to correlate soil factors with the decline of shisham in semiarid regions revealed that the $\mathrm{pH}, \mathrm{ECe}$, bulk density and calcium carbonate was found higher in soil under dead trees as compared to healthy trees. The value increased with increase in soil depth. The organic carbon and macro-nutrient (i.e. N, P, K, Ca, Mg and S) and micro-nutrients ( $\mathrm{Zn}, \mathrm{Fe}, \mathrm{Cu}$, and $\mathrm{Mn}$ ) were higher under healthy trees as compared to dead trees and their concentrations decreased with increase in soil depth both in case of healthy as well as dead trees of Dalbergia sissoo. Bimlendra and Datta (2007) noted that out of ten provenances of Acacia nilotica, salinity was found to be more deleterious for growth, development, metabolism, water relations and nutrients in 
three provenances, viz., Chandigarh, Banaskantha, and Bhopal.

\section{Materials and Methods}

The present investigation was conducted on two tree species i.e. Dalbergia sissoo Roxb. ex DC (Shisham) and Acacia nilotica (L.) willd. ex Delile (Kikar) growing under field conditions in Hisar district during the year 2011-2012. For this field surveys were made and sampling of soil and leaves was done. The soil and leaf samples were further analyzed in Stress Physiology Laboratory, Department of Botany \& Plant Physiology, Central Instrument Laboratory and Soil Science Laboratory at the CCS Haryana Agricultural University, Hisar. For the determination of soil $\mathrm{ECe}$ and $\mathrm{pH}$ soil was sampled at a distance of $1.5 \mathrm{~m}$ in the East, West, North and South from the main tree trunk. Soil was excavated to the depth of $1 \mathrm{~m}$ with the help of an auger and soil from all the four samples at 20-100 cm were homogenized and sieved. Each sample was processed for the preparation of soil saturation extract in the laboratory by gradual shaking and addition of distilled water to get a water saturated soil paste. The paste was vacuum filtered and electrical conductivity of soil saturation extract (ECe) was measured by using digital conductivity meter and expressed as $\mathrm{dS} \mathrm{m}^{-1}$ at $25^{0} \mathrm{C}$. Soil $\mathrm{pH}$ of the saturation extract was measured with the help of $\mathrm{pH}$ meter (Elico India).

$\mathrm{Ca}$ and $\mathrm{Mg}$ were estimated by EDTA titration according to the method given in USDA, Handbook (1954). Chloride was estimated by the method of Ramasay et al., (1955). $\mathrm{SO}_{4}$ was estimated by turbidimetric method as suggested by Chesnin and Yien (1950).

Data were subjected to analysis of variance (ANOVA) using online Statistical Analysis Package (OPSTAT, Computer Section, CCS
Haryana Agricultural University, Hisar, Haryana, India) and treatment means were compared by the least significant differences $(\mathrm{LSD})(\mathrm{p}<0.05)$.

\section{Results and Discussion}

It is seen in Figure 1 that sodium of Dalbergia sissoo was in the higher range of 1.8 to 2.9 $\mathrm{mg} / \mathrm{g}$ as compared to and 6.7 to $11.0 \mathrm{mg} / \mathrm{g}$ in trees growing under saline soils. In Acacia nilotica (Figure 2) a similar trend was observed with sodium in higher range of 7.7 to $12.9 \mathrm{mg} / \mathrm{g}$ in saline site trees as compared 2.2 to $2.7 \mathrm{mg} / \mathrm{g}$ in trees growing under non-saline sites. Bernstein (1965) reported severe leaf injury due to sodium or chloride salt in several fruit crops. These crops have little ability to exclude sodium or chloride from their leaves and are long-lived; hence, they often suffer toxicities at even moderate soil salinities.

Potassium of Dalbergia sissoo leaves was in the higher range of 29.3 to $34.0 \mathrm{mg} / \mathrm{g}$ as compared to and 22.0 to $25.3 \mathrm{mg} / \mathrm{g}$ in trees growing under saline soils (Figure 3 ). The result presented in Figure 4 show that a similar trend was observed in Acacia nilotica where potassium was again in the lower range of 21.0 to $25.0 \mathrm{mg} / \mathrm{g}$ saline site trees as compared 26.3 to $35.0 \mathrm{mg} / \mathrm{g}$ in trees growing under nonsaline sites. At low concentrations, sodium may actually increase potassium uptake, though decreasing it at higher concentrations (Nimbalkar and Joshi, 1975), but in most of the studies sodium salts decreased dry matter production and the leaf content of potassium as well as its uptake (Garg and Garg, 1980).

Chloride content of Dalbergia sissoo was in the lower range of 1.2 to $1.3 \mathrm{mg} / \mathrm{g}$ on the nonsaline sites as compared to and 3.4 to $5.5 \mathrm{mg} / \mathrm{g}$ in trees growing on saline sites (Figure 5). A similar trend was observed in Acacia nilotica where chloride was again in the higher range of 6.3 to $8.9 \mathrm{mg} / \mathrm{g}$ in saline site trees as 
compared 1.2 to $2.1 \mathrm{mg} / \mathrm{g}$ in trees growing under non-saline sites (Figure 6). Najafian et $a l$. , (2008) reported that in bitter almond the increase of salinity in irrigation water increased the accumulation of sodium and chloride in the shoot and root of the two rootstocks 31 and 41 .

It is seen in Figure 7 that sulphate content of Dalbergia sissoo leaves was in the lower range of 2.2 to $3.0 \mathrm{mg} / \mathrm{g}$ as compared to 7.4 to $7.8 \mathrm{mg} / \mathrm{g}$ in trees growing under saline soils. Acacia nilotica again showed higher sulphate range of 5.7 to $9.9 \mathrm{mg} / \mathrm{g}$ at saline site trees as compared 2.2 to $3.1 \mathrm{mg} / \mathrm{g}$ in trees growing on non-saline sites (Figure 8). The decrease was more in sulphate-dominated salinity as compared with chloride-dominated salinity (Kumari et al., 2008).

Fig.1 Sodium (Na) content of Dalbergia sissoo trees under non-saline (blue) and saline (red) sites

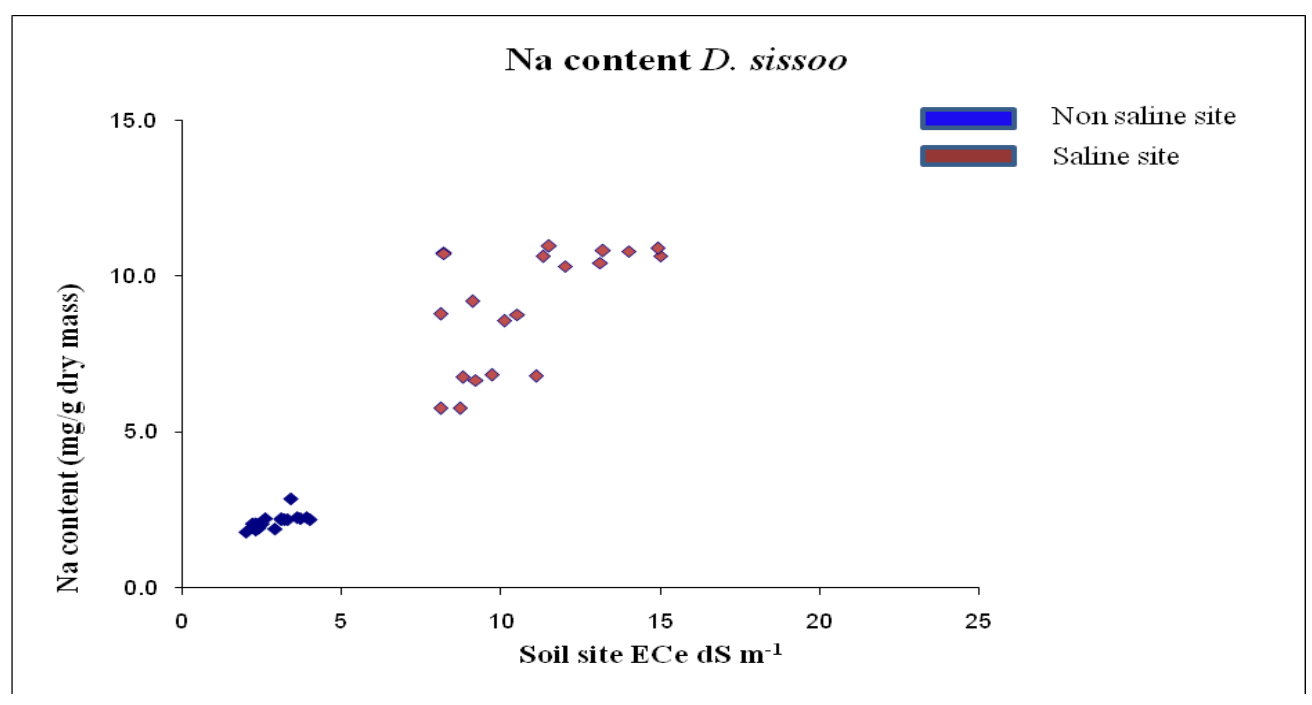

Fig.2 Sodium (Na) content of Acacia nilotica trees under non-saline (blue) and saline (red) sites

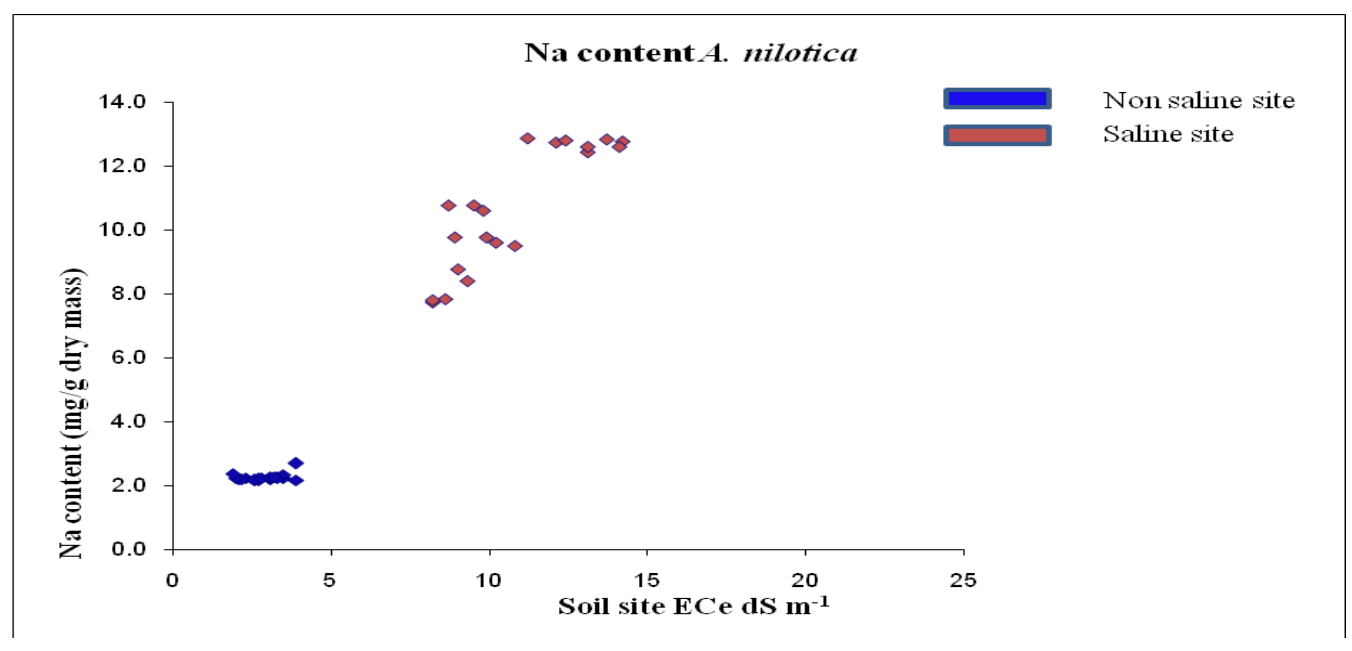


Fig.3 Potassium (K) content of Dalbergia sissoo trees under non-saline (blue) and saline (red) sites

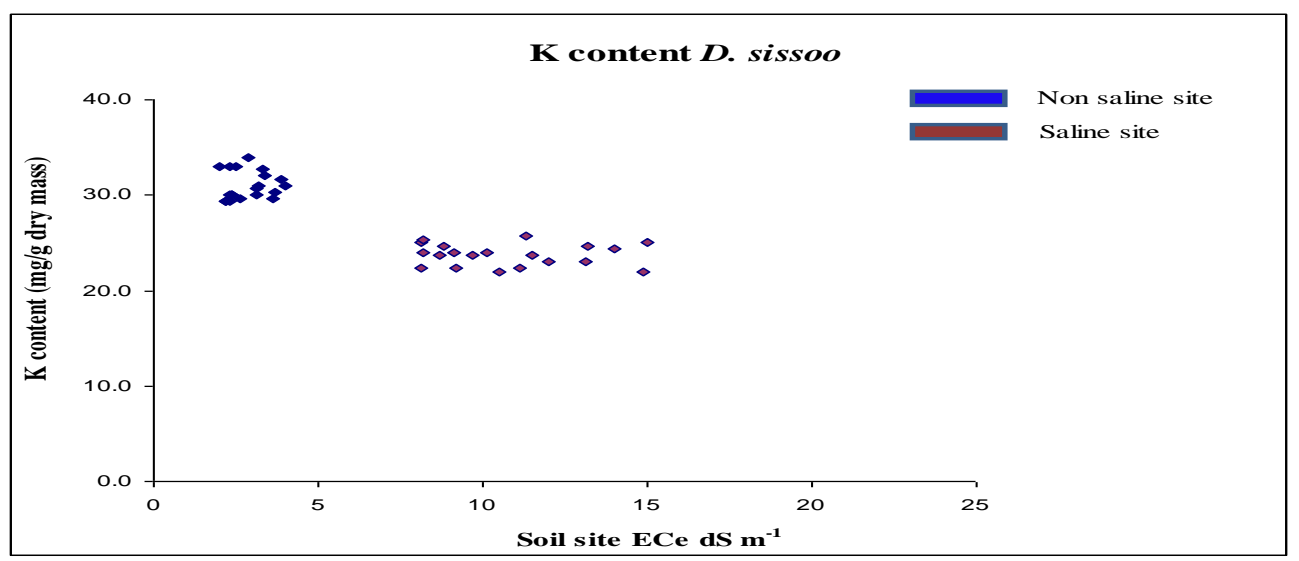

Fig.4 Potassium (K) content of Acacia nilotica trees under non-saline (blue) and saline (red) sites

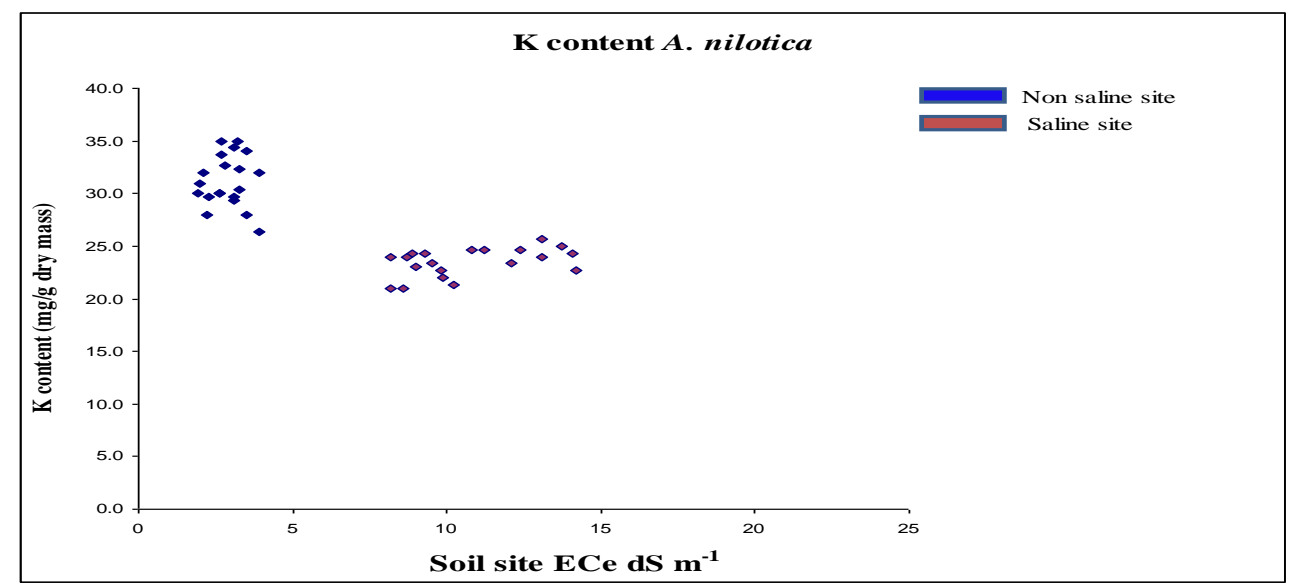

Fig.5 Chloride (Cl) content of Dalbergia sissoo trees under non-saline (blue) and saline (red) sites

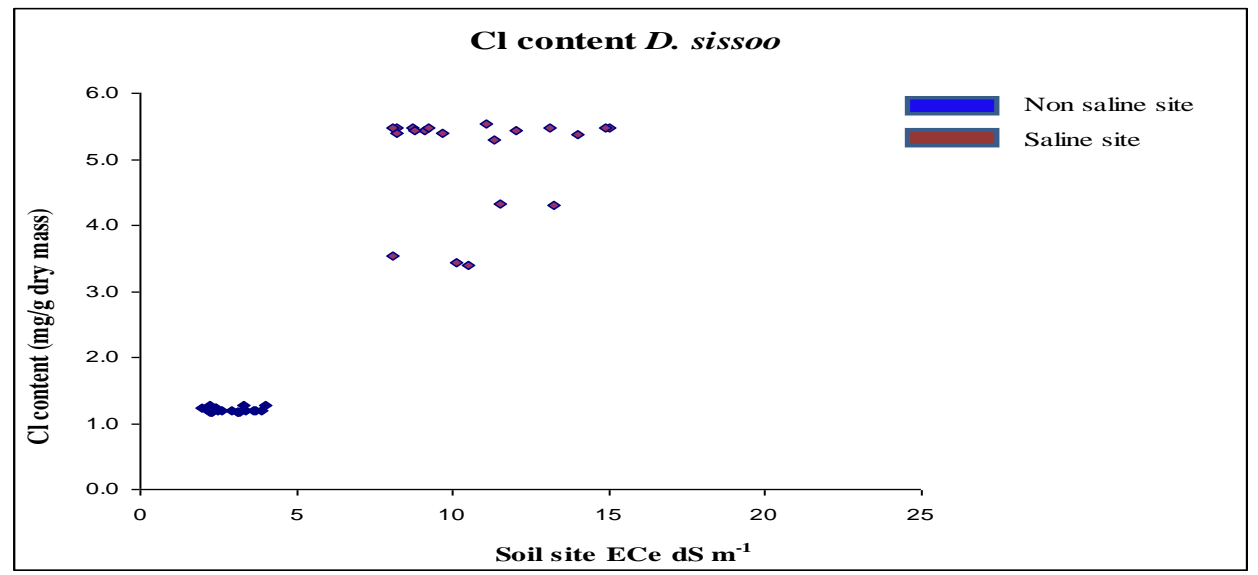


Fig.6 Chloride (Cl) content of Acacia nilotica trees under non-saline (blue) and saline (red) sites

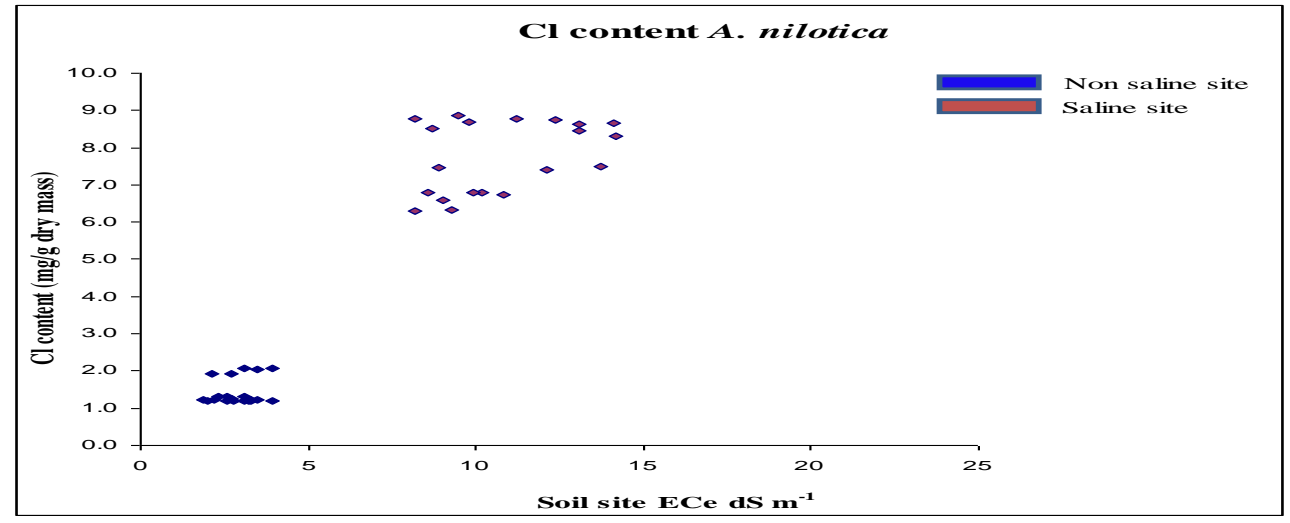

Fig.7 Sulphate $\left(\mathrm{SO}_{4}\right)$ content of Dalbergia sissoo trees under non-saline (blue) and saline (red) sites

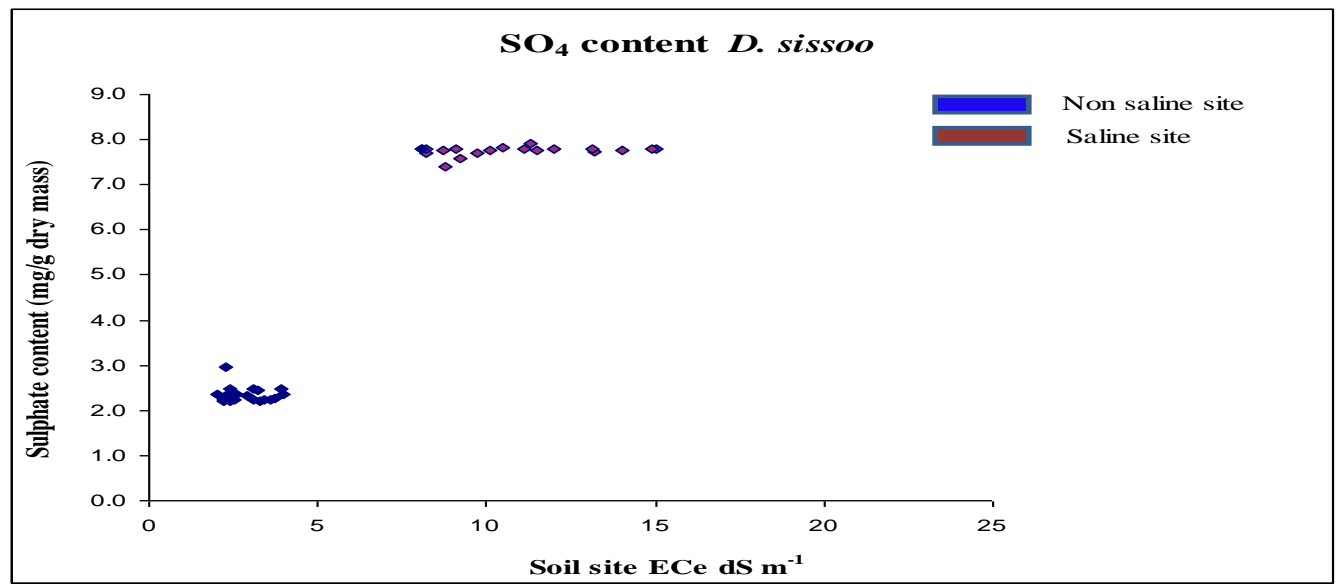

Fig.8 Sulphate $\left(\mathrm{SO}_{4}\right)$ content of Acacia nilotica trees under non-saline (blue) and saline (red) sites

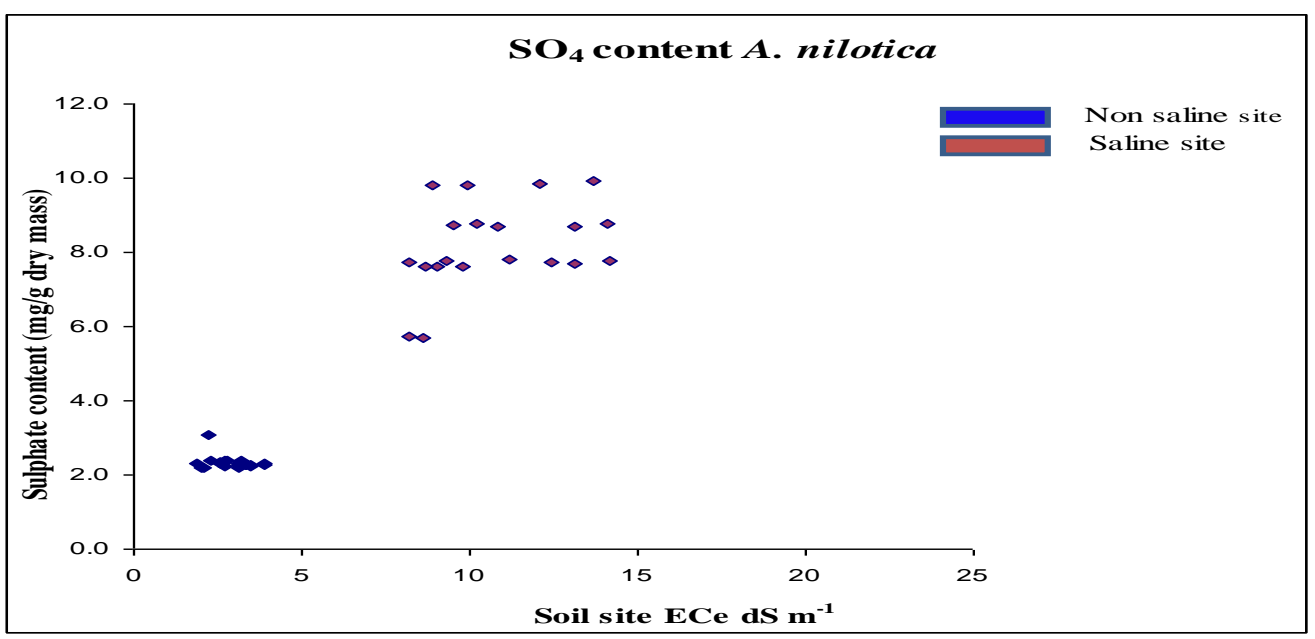


In conclusion considered in totality it would appear that the salinity in the soil profile has a perpetual retarding effect on various ionic content of Dalbergia sissoo as well as Acacia nilotica. This alone or in combination with other abiotic and biotic factors may lead to a slow decline and ultimate mortality of the trees.

\section{References}

Bernstein, L. (1965). Salt tolerance of fruit crops. United States Department of Agriculture, Agriculture Information Bulletin No. 292.

Bimlendra, K. and Datta, K.S. (2007). Mortality in Agroforestry trees. pp 150-155. Nandal D.P.S. \& Kaushik J.C. ed. Department of Forestry, CCS Haryana Agricultural University, Hisar.

Chesnin, L. and Yien, C.H. (1950). Turbidimetric determination of available sulphate. Soil Sci Soc. Am Proc.15: pp 149-151.

Garg, B.K. and Garg, O.P. (1980). Sodium carbonate and bicarbonate induced changes in growth, chlorophyll, nucleic acid and protein contents in leaves of Pisum sativum. Photosythetica.14: pp 594-598.

Hussain, G.S . Alshammary, F.(2008). Effect of water salinity on survival and growth of land scape trees in Saudi Arabia. Arid Land Research and Manage.22: pp 320 $-333$.

Kumari, B. Toky, O.P. (2008). Variation in nutrient and biochemical contents among provenances of Acacia nilotica (I.) under salinity stress. Annals of Biol. 29: pp 1-9.

Najafian, M. Rahemi and Tavallali, V. (2008). Effect of Salinity on Tolerance of Two Bitter Almond Rootstock. American
Eurasian J. Agric. and Environ. 3: pp 264-268.

Nimbalkar, J.D. and Joshi, G.V. (1975). Effect of salinity on germination, growth and mineral metabolism of sugarcane var CO. 740. J .Biol. Sci. 18: pp 53-63.

Ramsay, J.A. (1955). Electrometric titration of chloride in small volumes. J. Exp. Biol. 32: pp 822-829.

Schofield, N.J. (1992) Tree planting for Salinity control in Australia: Agroforest. Syst. 20: $1-23$

Singh, M.K. Kumar, R. Singh, R. (2007). Identification of the soil properties responsible for the decline of Dalbergia Sissoo. Proceedings of Regional Seminar on Mortality in Agroforestry Trees. pp 46-48 Eds. D.P.S Nandal \& J.C. Kaushik.

Sun, D. and Dickinson, G.R. (1995). Salinity effects on tree growth, root distribution and transpiration of Casuarina cunninghamiana and Eucalyptus camaldulensis planted on a saline site in tropical north Australia. For E.col. Manage. 77: pp 127-138.

Tanji, K.K. 1990. Agricultural Salinity Assessment and Management. Irrigation and Drainage Division, American Society of Civil Engineers, New York.

Tewari, P. Saxena, A.K. and Rao, O.P. (2006). Effect of sodicity and salinity on seedling growth of two early successional agroforestry tree species. Tropical Ecology. 47: pp 125-132.

USDA Handbook No. 60. (1954). Calcium and magnesium by Titration with Ethylene diamine tetraacetate (Versenate). The superintendent of Documents. U.S. Government Printing office Washington 25, D.C.

\section{How to cite this article:}

Dharamvir, Ajeev Kumar, Mahesh Kumar and Parveen Kumar 2018. Effect of Salinity to change on ionic Composition in D. sissoo and A. nilotica. Int.J.Curr.Microbiol.App.Sci. 7(12): 3598-3604. doi: https://doi.org/10.20546/ijcmas.2018.712.407 